\title{
The lichen genera Phaeographis and Phaeographina (Graphidaceae) in Australia 1: Species based on Australian type specimens
}

\author{
Alan W. Archer
}

\begin{abstract}
Archer, Alan W. (Royal Botanic Gardens Sydney, Mrs Macquaries Road, Sydney NSW 2000, Australia) 2000. The lichen genera Phaeographis and Phaeographina (Graphidaceae) in Australia 1. Species based on Australian type specimens. Telopea 8(4): 461-475. The types and other specimens of 14 Australian species in the genus Phaeographis (Graphidaceae) and 3 types and other specimens of Australian taxa in the genus Phaeographina (Graphidaceae) were examined. Phaeographina caesiopruinosa var. monospora Müll. Arg. is raised to species level as Phaeographina muelleri A.W. Archer. Phaeographis subcompulsa Müll. Arg., Phaeographis cinerascens Müll. Arg., Phaeographis inscripta Müll. Arg. and Graphis aulacothecia C. Knight are taxonomic synonyms of Phaeographis australiensis Müll. Arg., while Phaeographis subtricosa (C. Knight) Müll. Arg., Phaeographis intumescens Müll. Arg. and Phaeographis extenuata are taxonomic synonyms of Phaeographis subintricata Müll. Arg. Lectotypes are selected for Phaeographis australiensis Müll. Arg. and Graphis aulacothecia C. Knight. The ascospores in Phaeographis pseudomelana Müll. Arg. are 4-locular and not 6-locular as reported in the protologue.
\end{abstract}

\section{Introduction}

The lichen family Graphidaceae (the so-called Script Lichens) includes a number of genera which are separated by the structure and colour of the ascospores, the presence or absence of lirellae immersed in stromatic tissue and the structure of the paraphyses. The distinction between these genera is best shown in a simplified key.

\section{Key to the Australian Graphidaceae}

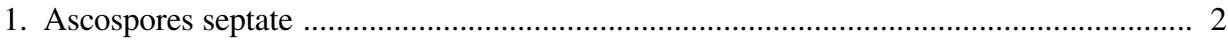

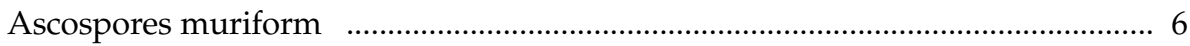

2. Ascospores hyaline ……………………………………………………….... 3

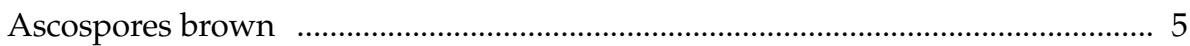

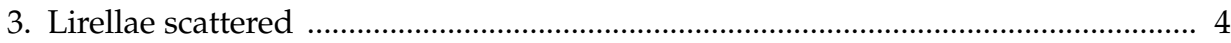

Lirellae grouped in stromatic tissue ....................................................... Glyphis

4. Paraphyses simple ............................................................................... Graphis

Paraphyses branched .................................................................... Diplogramma

5. Lirellae grouped in stromatic tissue ............................................... Sarcographa

Lirellae scattered …………………………………….............. Phaeographis

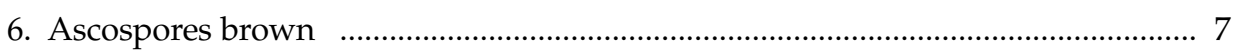

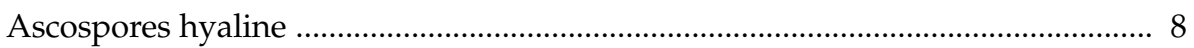


7. Lirellae grouped in stromatic tissue Sarcographina Lirellae single Phaeographina

8. Lirellae grouped in stromatic tissue Medusulina Lirellae single 9

9. Ascospores 1-8 per ascus; paraphyses simple Graphina Ascospores 1 per ascus; paraphyses branched Cyclographina

Apart from Glyphis (Acharius 1814), Sarcographa (Fée 1824) and Cyclographina (Awasthi \& Joshi 1979), the remaining genera were described by Müller: Graphina (1880), Phaeographis (1882a: 336), Phaeographina (1882a: 398), Sarcographina (1887b), Diplogramma (1891b) and Medusulina (1894).

The genera Phaeographis and Phaeographina were based on ascospore colour and structure only and were not universally accepted. Vainio, in his account of the lichen flora of Brazil (Vainio 1890), relegated them to subgenera in the genus Graphis and this arrangement was followed in his account of the Philippine Graphidaceae (1920). Later, however, botanists dealing with the Graphidaceae from the United States (Fink 1935), Brazil (Redinger 1933, 1935), Mexico (Wirth \& Hale 1963), New Zealand (Hayward 1977), Dominica (Wirth \& Hale 1978), the United Kingdom (Purvis et al. 1992) and Australia (Rogers \& Hafellner 1992) have accepted Müller's concept of the genera which has also been retained in the latest edition of the Dictionary of the Fungi (Hawksworth et al. 1995). A detailed description of each of the two genera is given by Rogers (1981).

Wirth and Hale (1978) discussed generic separation in the Graphidaceae and gave examples of borderline species which could be placed in either of two genera, e.g. Graphis or Graphina. They indicated the disadvantages of rejecting the spore-based genera which would, in their view, leave only two choices, viz: the creation of many more smaller genera with more closely related species, or the reduction of all the spore-based genera back into the genus Graphis, which contains over 1000 species. In the light of these difficulties they accepted, faute de mieux, the spore-based genera on the grounds of practicality.

The family Graphidaceae is predominantly tropical to subtropical with relatively fewer species found in temperate regions. For example only four Phaeographis species (and no Phaeographina species) are reported from Great Britain (Purvis 1992) in contrast to a total of 54 Phaeographis and Phaeographina taxa reported from Brazil (Redinger 1933) and 30 (including several unnamed species) from Australia.

The lirellae in Phaeographis and Phaeographina are often large and conspicuous but may be immersed and inconspicuous. Ascospores range from c. $20 \mu \mathrm{m}$ long and 4-locular to c. $200 \mu \mathrm{m}$ long and densely muriform. Lichen compounds are often absent but species may contain norstictic or stictic acids (common in the genera Graphis and Graphina) and recently nornotatic, hypoprotocetraric, echinocarpic and hypostictic acids were found in species of Phaeographis and Phaeographina from Australia and elsewhere (Archer \& Elix 1999).

As a number of new species and new reports remain to be published, a fuller treatment, with keys, is not provided here. 


\section{Material and methods}

The material examined consisted of type and other specimens from BRI, G, NSW and WELT and additional recent collections from CANB, ESS, GZU, herb. Hafellner, herb. Kalb and the author's own collections. The techniques used were described previously (Archer 1999) but cross sections of lirellae were drawn in the dry state and were later examined in water to determine the colour of the ascospores. Specimens were photographed at a magnification of 6.5 on Fujichrome ASA 100 film and converted to black and white, to give a final magnification of 17 .

\section{Phaeographis species}

Phaeographis australiensis Müll. Arg. (Fig. 1a, 2a)

(Müller 1882b: 504).

Lectotype (here selected): New South Wales: Parramatta, W. Woolls s.n. (G).

Phaeographis subcompulsa Müll. Arg.

(Müller 1882b: 503).

Type: New South Wales: Nepean River [Sydney], W. Woolls s.n., 1880 (holo G; iso MEL 515586).

Phaeographis cinerascens Müll. Arg.

(Müller 1882b: 503).

Type: New South Wales: Nepean River [near Sydney], W. Woolls 81 (holo G; iso MEL 515594).

Phaeographis inscripta Müll. Arg.

(Müller 1882b: 504).

Type: New South Wales: Nepean River [near Sydney], W. Woolls s.n. (holo G).

Graphis aulacothecia C. Knight

(C. Knight 1882: 41).

Lectotype (here selected): New South Wales: [near Sydney], C. Knight 7, Vol. 204, p. 7, 1880 (WELT); syntype: C. Knight 46, Vol. 204, p. 7, 1880 (WELT).

Thallus pale greyish white, thin, corticolous, surface slightly cracked, smooth and dull; apothecia lirelliform, conspicuous, black, numerous, straight or sinuous, sometimes branched, subimmersed to sessile, 1-3(-6) mm long, (0.15-)0.2-0.3 mm wide, lips closed or becoming slightly open, smooth, usually with a well-defined, but sometimes evanescent, thalline margin; proper exciple laterally or almost completely carbonised; hymenium (100-)120-150 $\mu \mathrm{m}$ tall; ascospores 8 per ascus, 2-seriate, fusiform, pale brown, (30-)35-45(-55) $\mu \mathrm{m}$ long, (5-)7-10 $\mu \mathrm{m}$ wide, (7-)8-10(-11)-locular.

Chemistry: norstictic acid.

Also examined (12 out of 78): Queensland: sine loc., Bailey 109, no date (BRI, AQ 720200); Woolston, S. Brisbane, Wilson 1636, Aug 1889 (NSW).

New South Wales: Border Ranges National Park, Lumbsch 11007c, Oct 1994 (ESS); Old Macleay River Estuary, Stuarts Point, Elix 21348, Jan 1987 (CANB); Gosford, Erina Creek, Elix 4701, May 1978 (CANB); 2 miles [3 km] N of Dural, Briggs L 586, Feb 1964 (NSW); Panania, Kelso Creek, Pinner 29, May 1998 (NSW); Mongarlowe River, 20 km SE of Braidwood, Streimann 36735, May 1986 (CANB). 


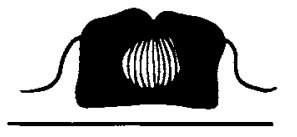

a

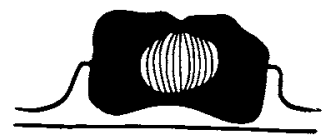

b

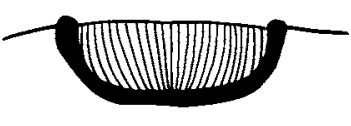

C
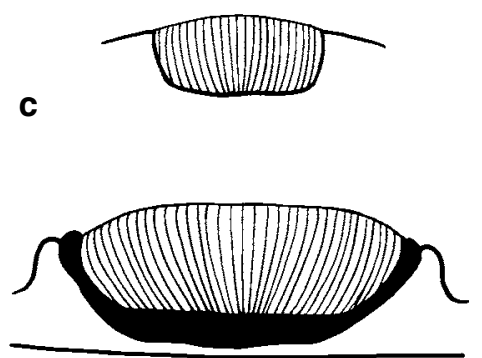

d
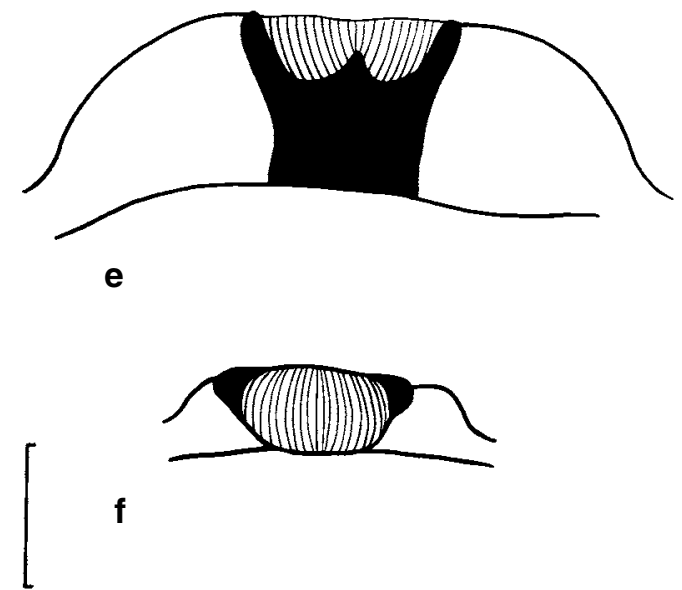

$\left(\begin{array}{l}0 \\ 0 \\ 0 \\ 0\end{array}\right)\left(\begin{array}{l}0 \\ 0 \\ 0 \\ 0\end{array}\right)\left(\begin{array}{l}0 \\ 0 \\ 0 \\ 0\end{array}\right)$

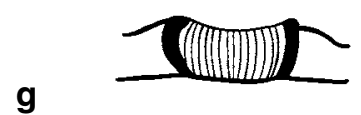

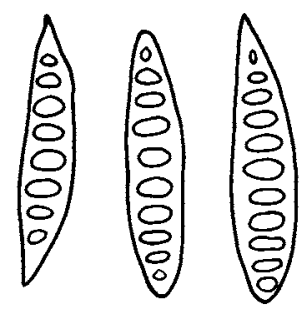

$\left(\begin{array}{lll}0 \\ 0 \\ 0 & 0 & 0 \\ 0 & 0 \\ 0 & 0 \\ 0 & 0 \\ 0\end{array}\right.$

(용 용 잉 (잉

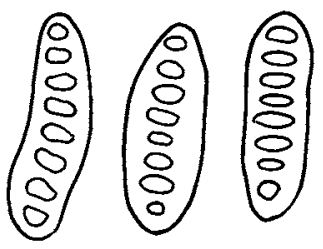

Fig.1. Cross-sections of lirellae and ascospores. a, Phaeographis australiensis; $\mathbf{b}$, P. elaeina; c, P. eludens; d, P. necopinata; e, P. nornotatica; f, P. pseudomelana; $\mathbf{g}$, P. subintricata. lirellae: scale bar $=200 \mu \mathrm{m}$; ascospores: scale bar $=20 \mu \mathrm{m}$. 
Victoria: Cunningham, Wilson 1494, Mar 1888 (NSW); Cunningham [Gippsland], Marlo, along Cape Conran Road, Verdon 4194, Nov 1978 (CANB).

Norfolk Island: Rocky Point Reserve, Streimann 31806, Dec 1984 (B, CANB).

Tasmania: Moores Hill, near Beaconsfield, Kantvilas 206/80, May 1980 (HO); Ringarooma Tier, Kantvilas 47/95, July 1995 (HO).

Phaeographis australiensis is characterised by the normally closed, black, lirelliform apothecia, the variably carbonised proper exciple and the presence of norstictic acid. When the lips are open the species somewhat resembles the chemically similar Graphis semiaperta Müll. Arg. but that species always has a completely carbonised proper exciple and smaller ascospores. The ascospores in P. australiensis are usually terminally rounded but may sometimes be terminally acute (Hayward 1977: 574, Fig. 7; Fig. 1a). The younger ascospores are often hyaline and older ascospores are conspicuously brown and shrivelled; on occasion, few mature brown ascospores may be seen.

Phaeographis australiensis is a common species which occurs in eastern Australia from Queensland to Tasmania and appears to be particularly abundant around Sydney. It occurs on a variety of substrates including species of Avicennia, Banksia, Cassia, Casuarina, Erythrina, Leptospermum, Ligustrum, Hakea, Malus, Melia, Persoonia, Pultenaea and Telopea. It also occurs on Norfolk Island and is reported from New Zealand (Hayward 1977).

Two syntypes of $P$. australiensis were seen. One of these is labelled 'LBn 533', a reference to Müller's publication in Flora, Lichenologische Beitrag no. 533, and is therefore selected as lectotype.

The type material of Graphis aulacothecia from WELT consists of 2 syntypes, Knight 7 and Knight 46. Of these, Knight 7 is the larger of the two specimens and is here selected as lectotype as the other smaller specimen has very few apothecia. Graphis aulacothecia was previously reported as a synonym of Phaeographis australiensis (Archer 1999).

The morphological variation found in the types of the five names cited above falls within the range of variation seen in the many recent collections. The four later names are based on material collected within a small area near Sydney and it is therefore not surprising that the 11 specimens belong to the same species.

Knight reported brown ascospores to be present in Graphis aulacothecia, and also in Graphis elaeina, G. subintricata and G. subtricosa (Knight 1882) but Müller transferred only the last three species to his new genus Phaeographis.

Phaeographis australiensis somewhat resembles P. mucronata (Stirt.) Zahlbr., according to the description given by Stirton (Stirton 1876), but the two species appear to be distinct. Phaeographis australiensis occurs predominantly in eastern New South Wales whereas P. mucronata was collected in the Riverina District in the west of the State. In addition, $P$. mucronata was reported to give no colour with alkali (K-ve) (Stirton, loc. cit.) suggesting the absence of norstictic acid, which is present in P. australiensis. The chemistry of $P$. mucronata has not been reported and the type was not available for examination.

Phaeographis elaeina (C. Knight) Müll. Arg. (Fig. 1b, 2b)

(Müller 1895: 321).

Graphis elaeina C. Knight

(Knight 1882: 41).

Type: New South Wales: [near Sydney], C. Knight 51 (holo G). 


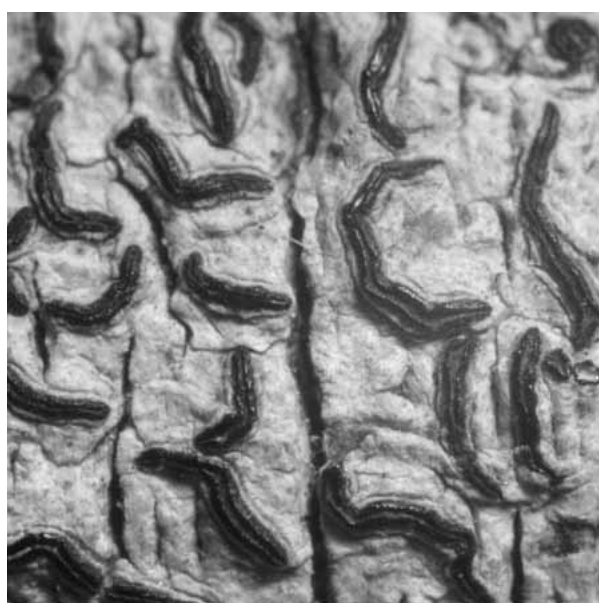

a
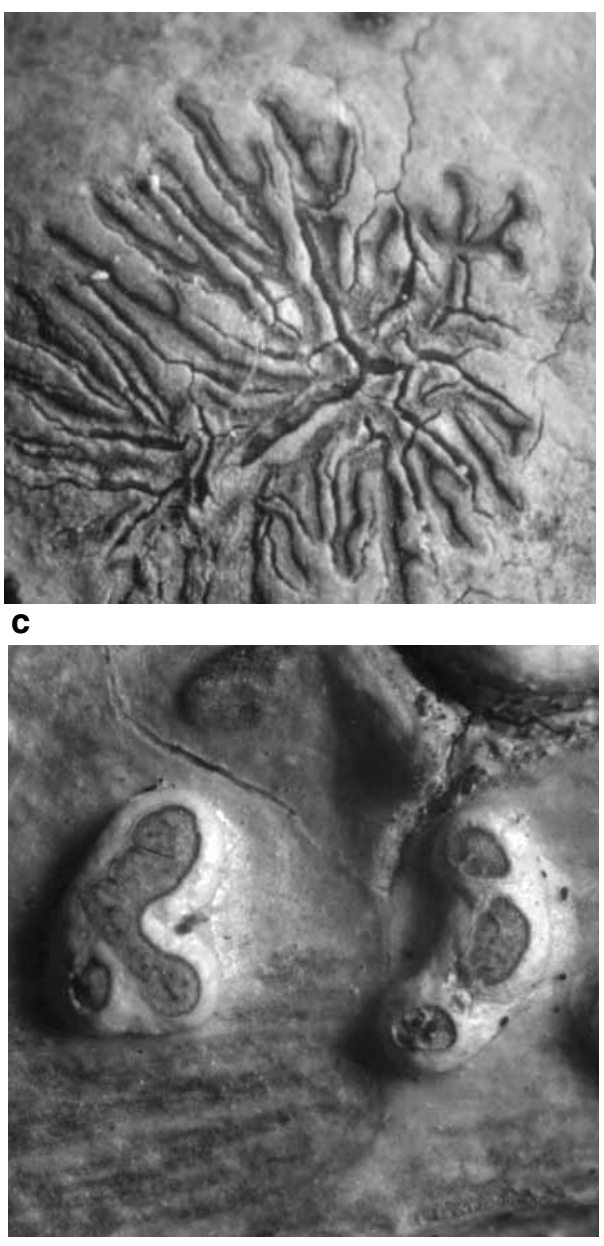

e

Fig. 2. a, Phaeographis australiensis Müll. Arg., lectotype (G); b, Phaeographis elaeina (C. Knight) Müll. Arg., holotype (G); c, Phaeographis eludens (Stirt.) Shirley, Elix 35177 (CANB); d, Phaeographis necopinata A.W. Archer \& Elix, holotype (CANB); e, Phaeographis nornotatica A.W. Archer \& Elix, holotype (CANB); f, Phaeographis pseudomelana Müll. Arg., holotype (G). All ×17.
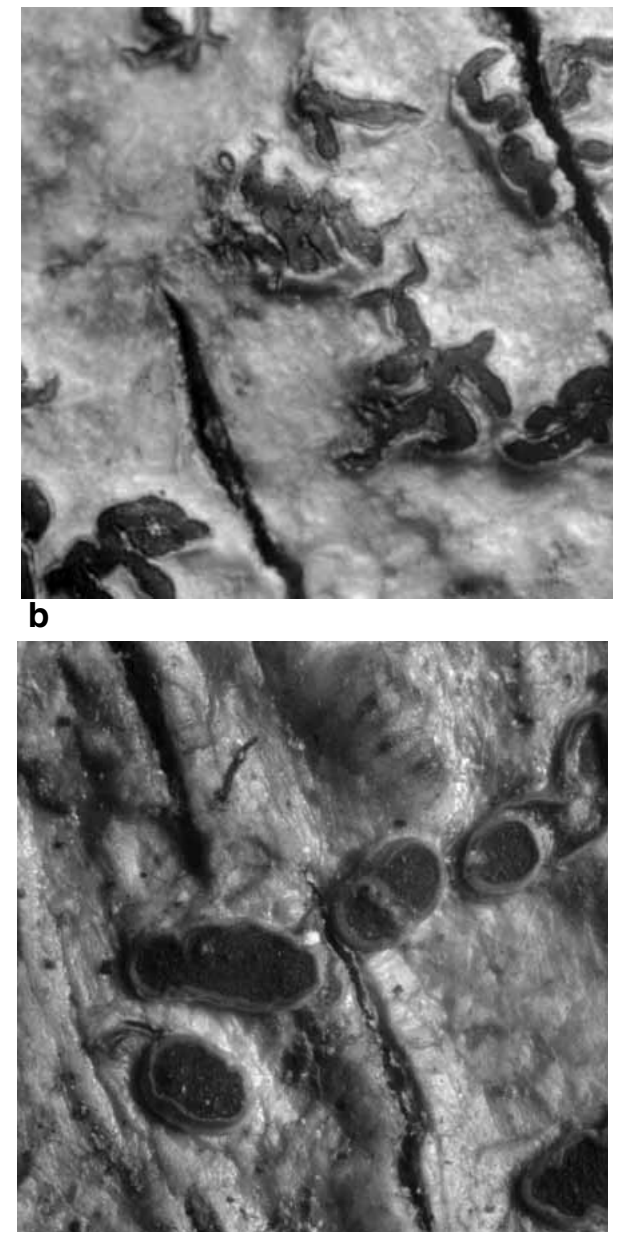

d

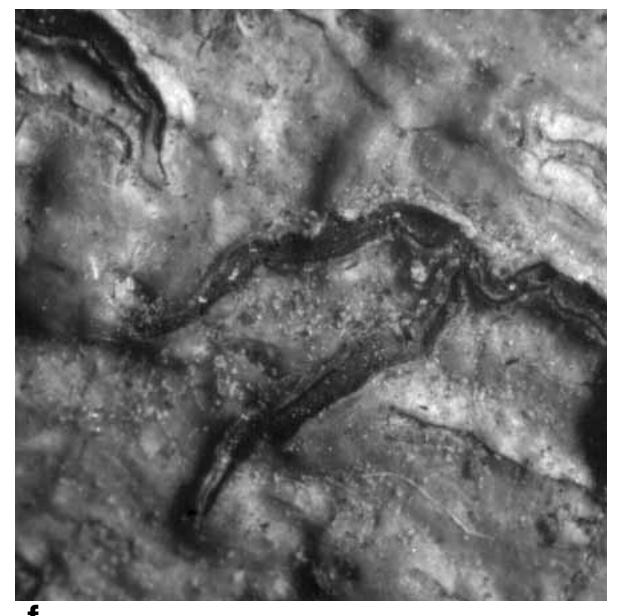

f 
Thallus off-white to pale olive green, thin, corticolous, surface smooth and shiny; apothecia lirelliform, black, conspicuous, immersed or sometimes subsessile, straight, curved or sinuous, sometimes branched, $1-4 \mathrm{~mm}$ long, $0.2-0.5 \mathrm{~mm}$ wide, often in substellate clusters to $4 \mathrm{~mm}$ wide, with a thin, white thalline margin; proper exciple thin, completely carbonised; hymenium (75-)100-125 $\mu \mathrm{m}$ tall; disc matt black, epruinose; ascospores 8 per ascus, irregularly 2-seriate, very pale brown, (15-)17-21(-23) $\mu \mathrm{m}$ long, 6-7 $\mu \mathrm{m}$ wide, 4-locular.

Chemistry: no compounds found.

Also examined: Queensland: New England Highway, $20 \mathrm{~km} \mathrm{SW}$ of Yarraman, Haffellner 19362, Sep 1986 (GZU); Conors Range, c. 20 km SW of Sarina, Lumbsch 10983d, p.p., Oct 1994 (ESS); Bowenia State Forest, Stony Creek, 25 km NNW of Yeppoon, Elix 34571, Aug 1993 (CANB); Forrest Beach, 16 km SE of Ingham, Streimann 28849, June 1984 (CANB); McIlwraith Range, 29 km NE of Coen, Streimann 56831, Oct 1995 (CANB).

New South Wales: Ku-ring-gai Chase National Park, the Basin camping area, on felled tree, Archer G261, Sep 1998, (NSW).

Phaeographis elaeina is characterised by the immersed, relatively wide, black lirellae, the 4-locular ascospores and the thin, completely carbonised proper exciple. This latter feature distinguishes the species from the somewhat similar P. subintricata, which has a thin carbonised proper exciple open at the base (laterally carbonised), and P. pseudomelana, which is apically carbonised. Phaeographis elaeina has been found in Queensland and New South Wales. Reported substrates include Casuarina and Excoecaria.

Phaeographis eludens (Stirt.) Shirley (Fig. 1c, 2c)

(Shirley 1889: 197).

Graphis eludens Stirt.

(Stirton 1881: 72).

Type: Queensland: sine loc., as 'saxicola', F. Bailey 287 (holo BRI).

Thallus fawn to pale fawn, 1-2 mm thick, saxicolous, surface smooth and dull (superficially resembling fine velvet); apothecia lirelliform, black, numerous, inconspicuous, open, immersed, straight, curved or sinuous, often branched and in sub-stellate clusters; individual lirellae $0.5-2 \mathrm{~mm}$ long, $0.1-0.2 \mathrm{~mm}$ wide, lacking a thalline margin; proper exciple absent; hymenium (100-)125-175(-200) $\mu \mathrm{m}$ tall; ascospores 8/ascus, 2-3-seriate, pale brown, 12-15 $\mu \mathrm{m}$ long, 5-7 $\mu \mathrm{m}$ wide, 4-locular.

Chemistry: no compounds found.

Also examined: Queensland: sine loc., Shirley s.n., Jan 1888 (NSW); Burleigh Heads National Park, on basalt boulders, Elix 1093, Aug 1975 (CANB); Isla Gorge National Park, 27 km NNE of Taroom, on sandstone rocks, Elix 35177, Aug 1993 (CANB); Tabletop, Harvey Range, 39 km WSW of Townsville, Streimann 37185, 37192, Aug 1986 (CANB).

Phaeographis eludens is characterised by the substrate preference, the thick thallus, the small 4-locular ascospores and the absence of lichen compounds. Stirton (1881) compared his new species with Graphis hypoglauca Krempelh. [Phaeographis hypoglauca (Krempelh.) Zahlbr.] but the ascospores in that species are larger, $18-28 \times 8-11 \mu \mathrm{m}$ (Singh \& Awasthi 1979).

The species is so far known only from Queensland where it occurs on basalt and sandstone. The species was also reported from Moggill and Mount Perry [Brisbane] (Shirley 1889). 
An unnamed saxicolous species of Phaeographis from Queensland with 4-locular ascospores (H. Streimann 56404, CANB) is differentiated from P. eludens by the tuberculate thallus and the conspicuous thalline margins of the lirellae.

Phaeographis necopinata A.W. Archer \& Elix (Fig. 1d, 2d)

(Archer \& Elix 1999: 92).

Type: Queensland: Great Dividing Range, Mount Baldy, $4 \mathrm{~km} \mathrm{~S}$ of Atherton, on Alphitonia, J.A. Elix 16233, June 1984 (holo CANB).

Thallus off-white, thin, corticolous, surface smooth and shiny; apothecia lirelliform; lirellae numerous, conspicuous, sessile, open, straight, curved or sinuous, sometimes in substellate clusters, with a thin thalline margin, $1-3 \mathrm{~mm}$ long, $0.3-0.5 \mathrm{~mm}$ wide, and clusters to $4 \mathrm{~mm}$ wide; proper exciple completely carbonised; hymenium 125-150 $\mu \mathrm{m}$ tall; epithecium matt black, epruinose or lightly pruinose; ascospores pale brown to brown, 8 per ascus, (25-)30-40 $\mu \mathrm{m}$ long, (8-)9-12 $\mu \mathrm{m}$ wide, (7-)8-locular.

Chemistry: hypostictic acid (major), conhypoprotocetraric acid (trace) and hyposalazinic acid (trace).

Also examined: Queensland: Lamb Range, 21 km NE of Atherton, Streimann 29822, June 1984 (CANB); Bellenden Ker, Mayrhofer 11921, Aug 1993 (GZU); type locality, Elix 16275, June 1984 (CANB).

Phaeographis necopinata is characterised by the conspicuous lirellae, asci with eight ascospores and the presence of hypostictic acid. The lirellae may be terminally rounded or acute and the ascospores are predominantly 8-locular. Superficially the new species resembles Phaeographis dendritica (Ach.) Müll. Arg., but is distinguished from that species by the presence of hypostictic acid. Hypostictic acid is an uncommon compound in the Graphidaceae but is also found in two species from Brazil, viz. the holotype of Graphina albostriata (Vain.) Zahlbr. (TUR-V 27177) and a syntype of Graphina pseudosophisticata (Vain.) Müll. Arg. (TUR-V 27244A) (Archer \& Elix 1999). These two taxa are conspecific.

Phaeographis nornotatica A.W. Archer \& Elix (Fig. 1e, 2e)

(Archer \& Elix 1999: 93).

Type: Queensland: McIlwraith Range, Llankelly Creek, 9 km NE of Coen, H. Streimann 56937, Oct 1995 (holo CANB).

Thallus dull fawn, thin, corticolous, surface smooth and shiny (chondroid); apothecia lirelliform, conspicuous, scattered, sessile, black, straight, curved or sinuous, sometimes branched, with a conspicuous thalline margin, lips open, disc black, fine white-pruinose, 1-4(-6) mm long, 0.5-0.7(-0.9) mm wide, 0.4-0.5 mm tall; proper exciple completely carbonised, laterally thin, the base thick, c. $250 \mu \mathrm{m}$ tall, tapering towards the base; hymenium c. $100 \mu \mathrm{m}$ tall; ascospores 8 per ascus, pale brown, rounded cylindrical, 21-25 $\mu \mathrm{m}$ long, 6-7 $\mu \mathrm{m}$ wide, 6-locular.

Chemistry: 4-O-demethylnotatic acid [nornotatic acid] (major) and hypoprotocetraric acid (minor).

Also examined: Queensland: Big Tableland, $26 \mathrm{~km}$ S of Cooktown, on Alphitonia, Elix 17243, July 1984 (CANB).

Phaeographis nornotatica is characterised by the large conspicuous lirellae, the tapering base of the proper exciple and the presence of nornotatic acid. The species somewhat resembles P. exaltata (Mont. \& v.d. Bosch) Müll. Arg. but the lirellae are larger and taller, and the proper exciple and the chemistry differ. Phaeographis exaltata lacks lichen compounds. The new species is so far known only from the two specimens cited above. 
Phaeographis pseudomelana Müll. Arg. (Fig. 1f, 2f)

(Müller 1895: 321).

Type: Queensland: sine loc., J. Shirley 1838, 1893 (holo G).

Thallus pale fawn, thin, corticolous, surface smooth and shiny; apothecia lirelliform, conspicuous, scattered, sessile, open, straight, curved or sinuous, often branched, terminally acute, with a thin thalline margin, 2-4(-6) $\mathrm{mm}$ long, 0.15-0.25 mm wide; proper exciple apically carbonised; hymenium 100-125 $\mu \mathrm{m}$ tall; disc black, whitepruinose; ascospores 8 per ascus imbricate 1-seriate, pale brown, 17-20 $\mu \mathrm{m}$ long, 6-8 $\mu \mathrm{m}$ wide, 4-locular.

Chemistry: no compounds found.

Also examined: Queensland: Rainbow Beach, c. $50 \mathrm{~km} \mathrm{~W}$ of Gympie, Lumbsch 10995j, Oct 1994 (ESS); Kirrima State Forest, 24 km WNW of Cardwell, Elix 15685, June 1984 (CANB).

New South Wales: Monga State Forest, J. Everett 947, May 1986 (NSW).

Phaeographis pseudomelana is characterised by the open lirellae, the apically carbonised proper exciple, the 4-locular ascospores and the absence of lichen compounds. It closely resembles P. subintricata (C. Knight) Müll. Arg. and is only distinguished from that species by the apically carbonised proper exciple, in contrast to the laterally carbonised proper exciple in the latter species. The type and other specimens examined possess 4-locular ascospores in agreement with Müller's drawing in sched. although the protologue refers to 6-locular ascospores. Shirley (1896) reported the species from Sankeys Scrub [Brisbane].

Phaeographis subintricata (C. Knight) Müll. Arg. (Fig. 1g, 4a)

(Müller 1895: 320).

Graphis subintricata C. Knight

(Knight 1882: 40).

Type: New South Wales: [near Sydney], C. Knight 41 (syntype WELT); additional syntype: G.

Phaeographis subtricosa (C. Knight) Müll. Arg.

(Müller 1895: 320).

Graphis subtricosa C. Knight

(Knight 1882: 40).

Type: New South Wales: [near Sydney], C. Knight (Vol. 69A, p.15), no. 6 (holo WELT; iso $G)$.

Phaeographis intumescens Müll. Arg.

(Müller 1893: 56).

Type: Victoria: Lakes Entrance, F.R.M. Wilson 877 (holo G).

Phaeographis extenuata Müll. Arg.

(Müller 1893: 57).

Type: Victoria: Lakes Entrance, F.R.M. Wilson 877 (holo G).

Thallus off-white to pale olive green, thin, corticolous, surface smooth and slightly shiny; apothecia lirelliform, black, conspicuous, open, immersed, becoming subsessile, 
straight, curved or sinuous, often branched, 1-4 mm long, $0.2-0.5 \mathrm{~mm}$ wide, often with a conspicuous, white thalline margin, sometimes forming substellate clusters; proper exciple thin, laterally carbonised, open at the base; hymenium 100-125 $\mu \mathrm{m}$ tall; disc matt black, epruinose; ascospores 8 per ascus, irregular 2-seriate, very pale brown, (14-)17-21(-24) $\mu \mathrm{m}$ long, 6-8 $\mu \mathrm{m}$ wide, 4-locular.

Chemistry: no compounds found.

Also examined: Queensland: Upper Coomera, Wilson s.n., as 'Graphis innata' (NSW).

New South Wales: Sydney, Mosman Bay, Wilson s.n., Sep 1897 (NSW); Urunga, Hungry Head, c. 25 km SSW of Coffs Harbour, Archer G 212, Apr 1998 (NSW).

Victoria: Cunningham, Wilson s.n., no date (NSW L5082); Metung, Wilson 877a, Mar 1889 (NSW); Lake Tyers, Wilson, no date (NSW 180877); Metung, Wilson s.n., Mar 1889 (NSW); Gippsland, 7 km S of Bonang, Verdon 4169, Nov 1978 (CANB, H).

New Zealand: sine loc., C. Knight s.n. [as Graphis hypoleuca, nom. nud.] (NSW 155588).

Phaeographis subintricata is characterised by the black, open lirellae, 4-locular ascospores, the incompletely carbonised proper exciple and the absence of lichen compounds. It resembles $P$. dendritica but is distinguished from that species by the smaller, 4-locular ascospores and the absence of norstictic acid. Phaeographis subintricata closely resembles P. elaeina and is only distinguished from that species by the completely carbonised proper exciple in the latter species, and from P. pseudomelana by the apically carbonised proper exciple in that species.

Graphis subintricata and Graphis subtricosa were published simultaneously (Knight 1882) and as G. subintricata is the first Graphis species described (no. 5; G. subtricosa no. 6) it is taken to be the earliest name. Phaeographis intumescens and P. extenuata were also published together (Müller 1893, loc. cit.) and are based on the same specimen, Wilson 877 , but the two new species were differentiated on the basis of the thallus colour. Müller (loc. cit., 1895) noted that P. subintricata was close to P. extenuata. The four species listed lack any features to distinguish between them.

Reported substrates include Acacia, Eucryphia, Lomatia and Notelaea.

Additional syntypes of P. subintricata are in G, M and WELT (Filson 1986) and as all of these have not been seen, no lectotype is selected here.

\section{Species of uncertain status}

Phaeographis mucronata (Stirt.) Zahlbr.

(Zahlbruckner 1923: 382)

Graphis mucronata Stirt.

(Stirton 1876: 95).

Lectotype (fide Rogers 1982): New South Wales: Riverina District, H. Paton s.n., 1875 (BM, not seen).

The type was not available for examination; see discussion above under Phaeographis australiensis. 


\section{Phaeographina species}

Phaeographina banksiae Müll. Arg. (Fig.3a, 4b)

(Müller 1893: 59).

Type: Victoria: Maffra, on Hymenanthera banksii, F.R.M. Wilson 879, 1892 (holo G; iso NSW).

Thallus pale reddish-brown, thin, corticolous, surface smooth and slightly shiny; apothecia lirelliform, black, numerous, conspicuous, sessile to slightly immersed, lips closed, becoming slightly open, straight or curved, rarely branched, 1-3 mm long, $0.2-0.3 \mathrm{~mm}$ wide, with a thin, evanescent thalline margin; proper exciple laterally carbonised; hymenium 125-150 $\mu \mathrm{m}$ tall; ascospores 8 per ascus, pale brown, ellipsoid, (20-)24-31(-39) × (10-)12-15(-17) $\mu \mathrm{m}, 4-6 \times 2-3$-locular.

Chemistry: no compounds found.

Also examined: Queensland: Upper Coomera, Wilson 1547, no date (NSW).

New South Wales: Jenolan Caves, Wilson s.n., Sep 1897 (NSW).

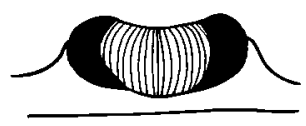

a

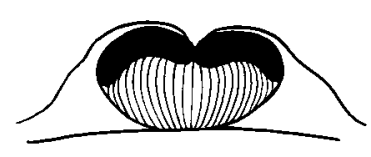

b
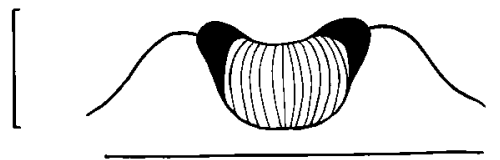

C
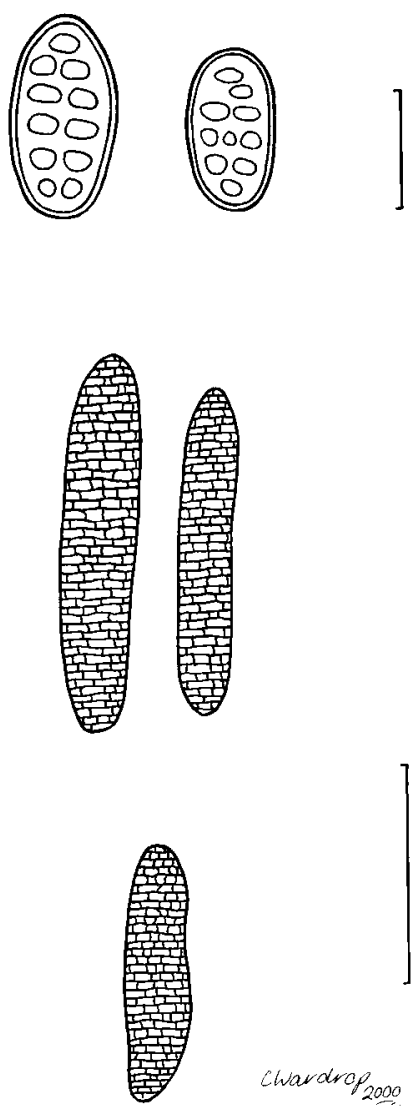

Fig. 3. Cross-sections of lirellae and ascospores. a, Phaeographina banksiae; b, P. echinocarpica; c, P. muelleri. lirellae: scale bar $=200 \mu \mathrm{m}$; ascospores: P. banksiae: scale bar $=20 \mu \mathrm{m}$, others: scale bar $=100 \mu \mathrm{m}$. 
Victoria: Maffra, Wilson s.n. (NSW L5084); Sale, on Grevillea robusta, Wilson 879, Sep 1886 (NSW); bank of Yarra River, Kew, Wilson s.n., Dec 1884 (NSW).

Phaeographina banksiae is characterised by the black lirellae, the laterally carbonised proper exciple, the small muriform ascospores and the absence of lichen compounds. It is distinguished from other Australian Phaeographina species by the small ascospores. The species is so far known from Queensland, New South Wales and Victoria.

Phaeographina echinocarpica A.W. Archer \& Elix (Fig. 3b, 4c)

(Archer \& Elix 1999: 91).

Type: Queensland: Mount Baldy, 4 km SW of Atherton, $17^{\circ} 17^{\prime} \mathrm{S}, 145^{\circ} 27^{\prime} \mathrm{E}$, alt. $1080 \mathrm{~m}$, in old Araucaria plantation and regrowth rainforest, on Alphitonia, J.A. Elix 16275, June 1984 (holo CANB).

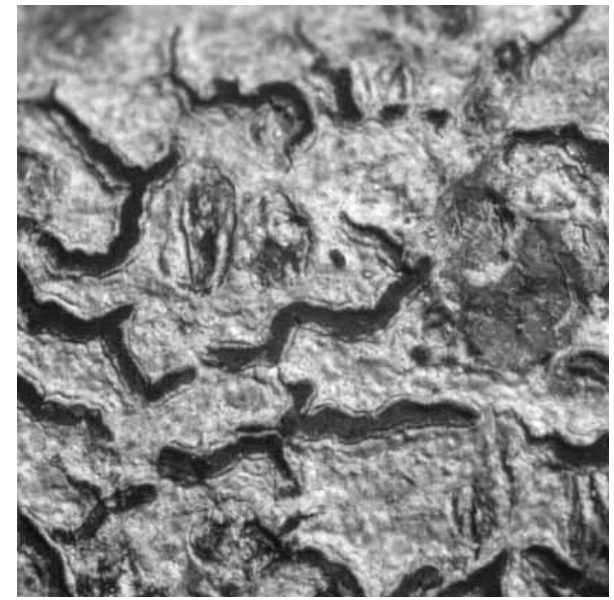

a

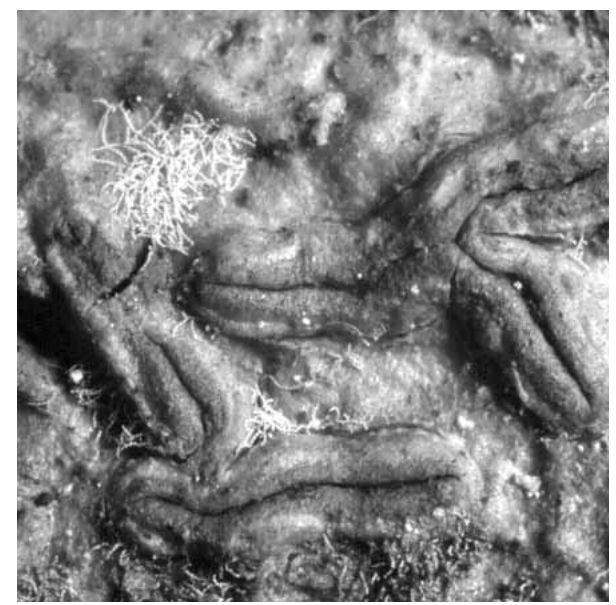

C

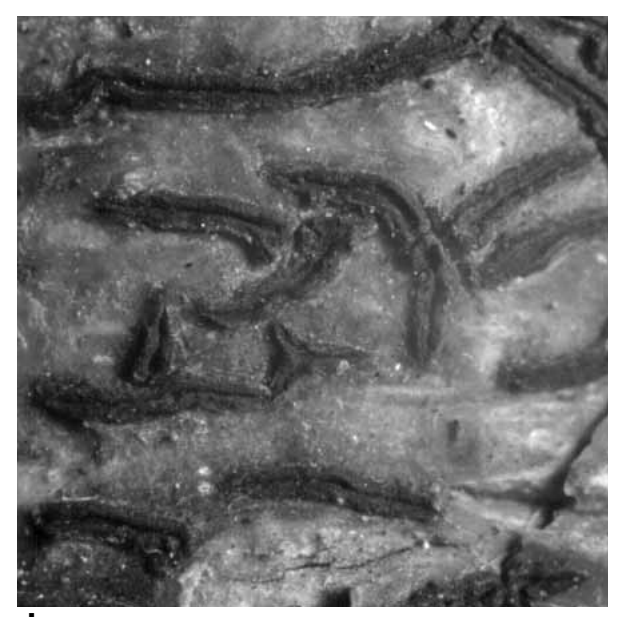

b

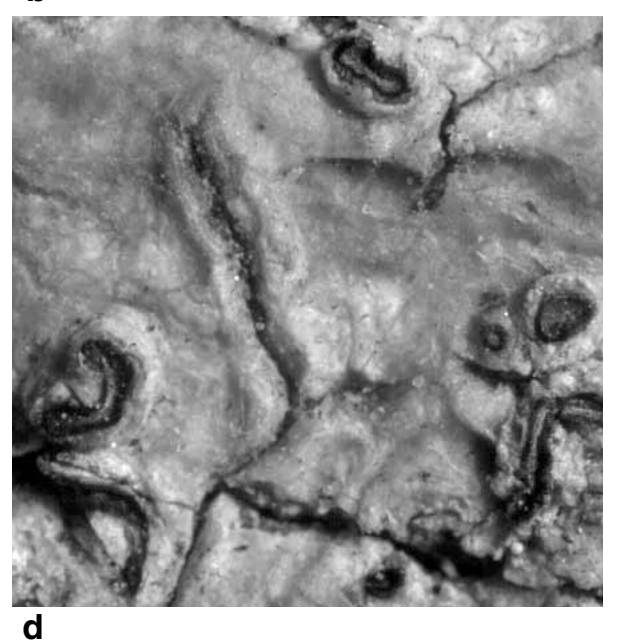

Fig. 4. a, Phaeographis subintricata (C. Knight) Müll. Arg., syntype (G); b, Phaeographina banksiae Müll. Arg., holotype (G); c, Phaeographina echinocarpica A.W. Archer \& Elix, holotype (CANB); d, Phaeographina muelleri A.W. Archer, holotype (G). All ×17. 
Thallus pale olive green, thin, corticolous, surface smooth and shiny. Lirellae conspicuous, numerous, scattered, sessile, greyish black, with conspicuous thalline margin, curved or sinuous, sometimes branched, 1-7 mm long, 0.7-0.9(-1.0) mm wide; proper exciple laterally carbonised, red-brown at the base; hymenium 200-250 $\mu \mathrm{m}$ tall; ascospores 1 per ascus, pale brown, elongate ellipsoid, 162-200 $\mu \mathrm{m}$ long, 30-40 $\mu \mathrm{m}$ wide, muriform (c. $20 \times 5-6$ locular).

Chemistry: echinocarpic acid (major) and 4-O-methylechinocarpic acid [conechinocarpic acid] (minor).

Also examined: Queensland: Cardwell Range, 46 km SE of Ravenshoe, Elix 16117 p.p, June 1984 (CANB).

Phaeographina echinocarpica is characterised by the large, pale brown ascospores, the conspicuous lirellae and the presence of echinocarpic acid. The carbonised proper exciple is covered with a thin thalline layer thus giving the lirellae a greyish black appearance.

Echinocarpic acid is an uncommon benzyl ester distinguished from other esters of this type, such as alectorialic acid and barbatolic acid, by ester formation involving an ortho- rather than a meta-hydroxymethyl group in the B-ring (Elix et al. 1995). Previously echinocarpic acid had been reported only from the Parmeliaceae.

The new species is distinguished from other species of Phaeographina with large ascospores, such as P. montagnei (v.d. Bosch) Müll. Arg. and P. muelleri (vide infra), by the presence of echinocarpic acid.

The species is so far known only from the two specimens cited.

Phaeographina muelleri A.W. Archer, sp. nov. (Fig. 3c, 4d)

Synonym: Phaeographina caesiopruinosa (Fée) Müll. Arg. var. monospora Müll. Arg., Bull. Herb. Boissier 3: 322 (1895).

Type: Queensland: Toowoomba, C. Hartmann s.n. (holo G).

Thallus pale fawn, thin, corticolous, surface smooth and shiny; apothecia lirelliform, conspicuous, scattered, conspicuously sessile, open, with a conspicuous thalline margin, 1-2 $\mathrm{mm}$ long, $0.3-0.7 \mathrm{~mm}$ wide; proper exciple apically carbonised; hymenium 175-200 $\mathrm{\mu m}$ tall; disc black, white-pruinose; ascospores 1 per ascus, elongate-ellipsoid, pale brown, 145-180 $\mu \mathrm{m}$ long, 30-40 $\mu \mathrm{m}$ wide, densely muriform.

Chemistry: no compounds found.

Phaeographina muelleri is characterised by the conspicuous, open, apically carbonised lirellae, the large muriform ascospores and the absence of lichen compounds. It is distinct from other species of Phaeographina with large ascospores and lacking lichen compounds which occur in Australia such as P. montagnei (v.d. Bosch) Müll. Arg., which has a bright red epithecium and a completely carbonised proper exciple, and an unnamed species from Queensland which has closed lirellae and lacks a carbonised proper exciple.

Phaeographina muelleri is so far known only from the type specimen.

Phaeographina caesiopruinosa (Fée) Müll. Arg. (Müller 1887a) is reported to be a common New World taxon with brown muriform ascospores, 4-8 per ascus, 45-120 $\times$ 15-20 $\mu \mathrm{m}$ and lacking lichen compounds (Müller 1894; Wirth \& Hale 1978). Müller (1887a) reported the taxon to occur in Ceylon and Java but it was not listed by Leighton from Ceylon (Leighton 1869) nor from Indonesia by Redinger (1936) and in addition it was not reported from adjacent areas such as Japan (Nakanishi 1966, 1977) and the Philippines (Vainio 1920). The taxon was reported from Queensland by Shirley 
(1891) and Müller (1891a, 1891b) but no specimens of the taxon were found in a recent examination by the author of Shirley and Bailey specimens from BRI and it has not been found among the many recent collections from Queensland in CANB. It is possible that the specimens examined were Phaeographina quassiicola (Fée) Müll. Arg., which has ascospores similar to those of P. caesiopruinosa. Phaeographina caesiopruinosa thus remains a New World species, confirmed by recent collections from Mexico (Wirth \& Hale 1963) and Dominica (Wirth \& Hale 1978). As var. caesiopruinosa appears to be absent from the Australian region and the Australian taxon is distinct from var. caesiopruinosa, in that it has an apically carbonised exciple and asci with one large ascospore, specific status is appropriate for the local Australian variety which is here named Phaeographina muelleri. The epithet commemorates the Swiss lichenologist Jean Müller of Argau (Müll. Arg.), 1826-1896, who described a large number of lichen taxa from Australia, including the present taxon.

\section{Acknowledgments}

The author is grateful to the Herbaria cited above for the loan of type and other specimens and to the National Herbarium of New South Wales (NSW) for permission to use the facilities of the Herbarium, for arranging the loan of the specimens cited above and to Ms. C. Wardrop (NSW) for the drawings.

\section{References}

Acharius, E. (1814) Glyphis. Syn. Lich.: 106 (Svandborg et Soc.: Lund).

Archer, A.W. (1999) The lichen genera Graphis and Graphina (Graphidaceae) in Australia 1. Species based on Australian type specimens. Telopea 8: 273-295.

Archer, A.W. \& Elix, J.A. (1999) Three new species in the Australian Graphidaceae with novel chemistries: Phaeographina echinocarpica, Phaeographis necopinata and Phaeographis nornotatica. Mycotaxon 72: 91-96.

Awasthi, D.D. \& Joshi, M. (1979) The lichen genera Helminthocarpon, Cyclographa and Cyclographina (gen. nov.). Norweg. J. Bot. 26: 165-177.

Elix, J.A., Lajide, L. \& Wardlaw, J.H. (1995) The structure of echinocarpic acid. A benzyl ester from Parmelia norcrambidocarpa. Austral. J. Chem. 48: 1213-1216.

Filson, R.B. (1986) Index to type specimens of Australian lichens 1800-1984. Australian Flora and Fauna Series Number 4 (Australian Government Publishing Service: Canberra).

Fink, B. (1935) The Lichen Flora of the United States: 106-119 (The University of Michigan Press: Ann Arbor).

Hawksworth, D.J., Kirk, P.M., Sutton, B.C. \& Pegler, D.N. (1995) Dictionary of the Fungi. (University Press: Cambridge).

Hayward, G.C. (1977) Taxonomy of the lichen families Graphidaceae and Opegraphaceae in New Zealand. New Zealand J. Bot. 15: 565-584.

Knight, C. (1882) Contributions to the Lichenographia of New South Wales. Trans. Linn. Soc. London, Bot. 2: 37-51.

Leighton, W.A. (1869) The Lichens of Ceylon. Trans. Linn. Soc. Lond. (Bot) 27: 161-185.

Müller, J. (1880) Lichenologische Beiträge X. Flora 63: 17-22.

Müller, J. (1882a) Lichenologische Beiträge XV. Flora 65: 326-337, 397-402.

Müller, J. (1882b) Lichenologische Beiträge XVI. Flora 65: 483-490, 499-505.

Müller, J. (1887a) Graphideae Féeanae. Mém. Soc. Phys. Hist. Nat. de Genève 29: 1-80.

Müller, J. (1887b) Lichenologische Beiträge XXVI. Flora 70: 423-429.

Müller, J. (1891a) Lichenes Bellendenici. Hedwigia 30: 47-56.

Müller, J. (1891b) Lichenes Brisbanenses. Nuov. Giorn. Bot. Ital. 23: 385-404.

Müller, J. (1893) Lichenes Wilsoniani. Bull. Herb. Boissier 1: 33-65.

Müller, J. (1894) Lichenes Eckfeldtiani in Louisiana et Florida. Bull. Herb. Boissier 2: 41-50; 89-93.

Müller, J. (1895) Sertum Australiense. Bull. Herb. Boissier 3: 313-327. 
Nakanishi, M (1966) Taxonomical Studies on the family Graphidaceae of Japan. J. Sci. Hiroshima Univ., Ser. B, Div. 2, Bot. 11: 1-126.

Nakanishi, M. (1977) Notes on Japanese species of Phaeographina. Hikobia 8: 91-100.

Purvis, O.W., Coppins, B.J., Hawksworth, D.J., James, P.W., \& Moore, D.M. (1992) The Lichen Flora of Great Britain and Ireland. (Natural History Museum Publications: London).

Redinger, K.M. (1933) Die Graphideen der ersten Regnell'schen Expedition nach Brasilien, 1892-1894. II: Graphina und Phaeographina. Ark. Bot. 26A(1): 1-105.

Redinger, K.M. (1935) Die Graphideen der ersten Regnell'schen Expedition nach Brasilien, 1892-1894. III: Graphis und Phaeographis. Ark. Bot. 27A(3): 1-103.

Redinger, K.M. (1936) Die Graphideen der Sunda Inseln. Rev. Bryol. Lichénol. 9: 37-122.

Rogers, R.W. (1981) The Genera of Australian Lichens (Lichenised Fungi). (University of Queensland Press: St. Lucia).

Rogers, R.W. (1982) Typification of the species of lichens described from Australian specimens by James Stirton. Austrobaileya 1: 502-510.

Rogers, R.W \& Hafellner, J. (1992) A systematic arrangement of the Australian lichens. Flora of Australia 54: 46-65.

Shirley, J. (1889) The lichen Flora of Queensland. Proc. Roy. Soc. Queensland 6:165-218.

Shirley, J. (1891) Lichenes. In Bailey, F.M., Contributions to the Queensland Flora. Queensland Dept. Agric. Bulletin 9, Botany Bulletin s.n. [3:] 29-30.

Shirley, J. (1896) Lichenes. In Bailey, F.M., Contributions to the Queensland Flora. Queensland Dept. of Agric. Bulletin s.n., Botany Bulletin XIII: 27-28.

Singh, K.P. \& Awasthi, D.D. (1979) Lichen genus Phaeographis from India and Ceylon. Bull. Bot. Surv. India 21: 97-120.

Stirton, J. (1876) Lichens British and Foreign. Trans. Glasgow Field Naturalists 4: 85-95.

Stirton, J. (1881) Additions to the lichen Flora of Queensland. Trans E Proc. Roy. Soc. Victoria 17: 66-78.

Vainio, E.A. (1890) $f$ tude sur la classification naturelle et la morphologie des Lichens du Bresil. Acta Soc. Fauna Fl. Fenn. 7: 1-247.

Vainio, E.A. (1920) Lichenes insularum Philippinarum III. Ann. Acad. Sci. Fenn., Ser. A. 15, 6: 1-368.

Wirth, M. \& Hale M.E. (1963) The lichen family Graphidaceae in Mexico. Contr. U. S. Natl. Herb. 36: 63-119.

Wirth, M. \& Hale M.E. (1978) Morden-Smithsonian Expedition to Dominica: The Lichens (Graphidaceae). Smithsonian Contr. Botany: 1-64.

Zahlbruckner, A. (1923) Catalogus lichenum universalis, vol. 2. (Borntraeger: Leipzig).

Manuscript received 2 September 1999

Manuscript accepted 15 May 2000 
